\title{
Identification of Giardia lamblia, Entamoeba histolytica and Cryptosporidium sp. in Feces of Diarrheal Patient at Puskesmas Jatinangor, September-November 2012
}

\author{
Komathi Palani, ${ }^{1}$ Lia Faridah, ${ }^{2}$ Uun Sumardi ${ }^{3}$ \\ ${ }^{1}$ Faculty of Medicine Universitas Padjadjaran, ${ }^{2}$ Department of Microbiology and Parasitology \\ Faculty of Medicine Universitas Padjadjaran, ${ }^{3}$ Department of Internal Medicine Faculty of \\ Medicine, Universitas Padjadjaran/Dr. Hasan Sadikin General Hospital Bandung, Indonesia
}

\begin{abstract}
Background: Diarrhea is one of the main public health problems occurring in West Java. One of the affected areas is Subdistrict Jatinangor. Inappropriate management of sanitation facilities around Jatinangor area causes contamination of water. Cikeruh River is one of the water sources in Jatinangor Area, from which people obtain water for daily activities. Water borne illness due to poor sanitation condition can lead to parasitic infection such as Giardia lamblia, Entamoeba histolytica and Cryptosporidium parvum which can cause a prolonged diarrhea. There has not been any study done regarding the presence of parasitical infection causing diarrhea around Jatinangor.

Methods: In order to identify the parasitic infection, a descriptive study was carried out on 16 fecal samples collected from diarrheal patient who visited Puskesmas Jatinangor from September-November 2012. The parasites were checked by using wet mount method

Results: The parasites found were Entamoeba histolytica, Cryptosporidium parvum, but none of Giardia lamblia. There were also other findings such as Iodamoeba butschlii and Entamoeba coli.

Conclusion: Positive findings of Entamoeba histolytica and Cryptosporidium parvum in diarrhea patients is most probably due to contaminated water and food. Measures need to be done to improve sanitary condition in Cikeruh River to prevent diarrhea. [AMJ.2015;2(1):213-16]
\end{abstract}

Keywords: Cryptosporidium parvum, diarrhea, Entamoeba histolytica, Giardia lamblia

\section{Introduction}

Every year, diarrhea cases occur around 2 billion and can affect people of different ages and sexes worldwide. Diarrhea is defined as a passage of watery stool for three times or more in a day. Diarrhea can be caused by infectious agents for example: bacteria, virus, and parasite that could be transmitted through poisoned food or polluted water or poor sanitation condition of a person. Statistically, diarrhea is the second major causing death worldwide for children under age $5 .{ }^{1}$ Mostly, more than eighty percent of mortality rate occurs in Southeast Asia and Africa. ${ }^{2}$

Approximately 1.5 billion people has poor management of improved water and 2.5 billion people has poor sanitation condition worldwide. $^{1}$ Parasites usually will be more prominent in areas that has dirty environment and they live most commonly in war and moist places thus they grow fruitly in tropical countries. ${ }^{3}$ Basically, among the parasites that causes infection leading to diarrhea, there are three species that most commonly can be seen in feces of a diarrheal patient. They are Giardia lamblia, Entamoeba histolytica, and Cryptosporidium parvum., based on previous research done in Bekasi, West Java, Indonesia and Bangladesh., ${ }^{4,5}$

Diarrhea is one of main public health problems occur in West Java. In year of 2006, the incidence of diarrheal cases occur in West Java was 1.136 .447 cases. This is due to poor sanitation condition, also due to improper water supply in the rural side. ${ }^{6}$

Subdistrict Jatinangor is a place in Sumedang Regency, West Java Province that consists of 12 villages. ${ }^{7}$ Location of Subdistrict Jatinangor is in exactly in the center of Sumedang and directly adjacent to Cikeruh River. So, this makes Cikeruh River is the one of the water supplies for this area. Inappropriate management of the sanitation facilities in

Correspondence: Komathi Palani, Faculty of Medicine, Universitas Padjadjaran, Jalan Raya Bandung-Sumedang Km.21, Jatinangor, Sumedang, Indonesia, Phone: +6287827934648 Email: kom_rocks@yahoo.com 
this area causes water in Cikeruh River to be contaminated. Previously, this has caused an increase percentage of people suffered from diarrhea in that area in August 2008. ${ }^{8}$ There has not been any study done regarding the presence of parasitical infection causing diarrhea around Jatinangor.

\section{Methods}

A descriptive study was done on fecal samples collected from diarrheal patient who visited Public Health Center/Pusat Kesehatan Masyarakat (Puskesmas) Jatinangor from September-November 2012. The parasites were checked by using wet mount method in Parasitology Laboratory in Universitas Padjadjaran.

The inclusion criteria was people diagnosed with diarrhea who has signed their informed consent to cooperate with this study whereas the exclusion criteria was people who already had treated with drugs, like metronidazole.

Sixteen stool samples were collected with a clean, leak-proof plastic container with applicator of spoon attached to screw cup. ${ }^{9,10}$ Using the spoon, stool was placed to a container and immediately transferred it into point of sample collection. Then, sample was labeled and given to laboratory to check or determine the presence of parasites in their feces. ${ }^{9,10}$ Before giving the specimen to laboratory, the specimen should be mixed with parasitology transport pack which was $10 \%$ formalin or polyvinyl isonyl alcohol (PVA), 3 parts stool to 1 preservative part and transported the specimen in room temperature condition in containers sealed in plastic bags. ${ }^{10}$

Stool examination can be done by using either direct method or concentrated techniques for the patients. Direct method examination was carried out by taking direct smear and two preparations were made. The first one was with saline solution and another one was with lugol and iodine solution. One drop of saline solution was poured in center of first slide and one drop of $1 \%$ lugol and 50 $\%$ iodine was poured into the second slide to check the presence of protozoa's trophozoite and cysts. The stool specimen was taken using the applicator stick and was emulsified with the saline and iodine solution. Thin film was prepared on each slide by mixing stool with a drop of normal saline and iodine solution. Cover glass was added and preparation was observed under microscope with 10x objective and $40 \times$ objective. ${ }^{11}$

\section{Results}

From sixteen fecal samples collected from diarrheal patient, the parasites found were Entamoeba histolytica (2), Cryptosporidium parvum (3), but none of Giardia lamblia. There were also other findings such as Iodamoeba butschlii (1) and Entamoeba coli (6).

\section{Discussion}

The expected parasitic findings in this study are Entamoeba histolytica, Cryptosporidium parvum and Giardia lamblia. However, based on Table 1, this study only finds Entamoeba histolytica in form of cyst and Cryptosporidium parvum. There are also other findings which are Entamoeba coli in form of cyst and Iodamoeba butschlii in form of trophozoite.

Positive findings of Entamoeba histolytica in cyst form are due to the ability of cyst to live in damp and wet conditions especially outside the host in water, food and soils. ${ }^{12}$ Positive findings of Cryptosporidium parvum

Table 1 Result of Parasitic Findings on Feces of Diarrheal Patient In Puskesmas Jatinangor

\begin{tabular}{lc}
\hline \multicolumn{1}{c}{ Species } & No. of Sample \\
\hline Expected findings & 0 \\
Giardia lamblia & 2 \\
Entamoeba histolytica & 3 \\
Cryptosporidium parvum & \\
Other findings & 1 \\
Iodamoeba butschlii & 6 \\
Entamoeba coli & 4 \\
No findings & \\
\hline
\end{tabular}


Komathi Palani, Lia Faridah, Uun Sumardi: Identification of Giardia lamblia, Entamoeba histolytica anख15 Cryptosporidium sp. in Feces of Diarrheal Patient at Puskesmas Jatinangor, September-November 2012

are due to ability of oocyst of living in long duration in water even added with chlorine. Cryptosporidium parvum is also known as 'chlorine tolerant pathogen' due to ability of the oocyst to survive in chlorine added water for 3.5 to 10.6 days. ${ }^{13}$ Therefore, those carriers who are symptomatic who pass the cyst through feces become the main source of contaminated food and water. Thus, patients affected by both these parasites are due to contaminated water and food which is at high risk of having poor sanitation condition. ${ }^{14}$ This is supported also by a research done in Saudi Arabia, where there were also findings on Entamoeba histolytica in feces of diarrheal patient due to poor sanitation condition. ${ }^{11}$

There are negative findings on Giardia lamblia because there is decrease test sensitivity in identifying Giardia lamblia in single sample of feces, as proved by Cartwright which was only to be $74 \%$. Decrease in test sensitivity in identifying Giardia lamblia in feces of diarrheal patient can be caused by excretion that is varied and low level of shedding of the parasites on the patients. ${ }^{15}$ In order to increase test sensitivity in identifying Giardia lamblia in sample of feces, three sample of feces must be collected on separate days which also known as 'multiple stool collection. ${ }^{13,16}$

Other findings are the presence of Entamoeba coli in cyst and trophozoite form and Iodamoeba butschlii. Even though Entamoeba coli and Iodamoeba butschlii, Entamoeba histolytica are in same class of Amoeba, Iodamoeba butschlii and Entamoeba coli are known as nonpathogenic parasites. ${ }^{14,17}$ Both species reside in gastrointestinal tract of human and have similar form of infection as pathogenic parasites, Entamoeba histolytica. ${ }^{17}$ In this case, both of these species are noninvasive and present in form of cyst and trophozoite. Usually, cysts of both of these species can be identified in formed stool meanwhile trophozoite of both this species can be identified in feces of diarrheal patients. ${ }^{12}$ Even though they are commensal parasites in human, their structure morphological form are often confused/exchanged with the structure and morphological form of Entamoeba histolytica, which looks similar. ${ }^{12}$ However those species of parasites which are nonpathogenic can turn out to be pathogenic in people who has HIV positive, as proved by a survey done in United States of America, more than $50 \%$ of asymptomatic people who had HIV positive usually tested positive for at least one intestinal parasite. Thus, all species of parasites compromise human immune system and worsen the condition of those with HIV positive. ${ }^{18}$

Due to limitation of study, the number of sample was limited. Measures should be done to improve sanitary condition around Cikeruh River to prevent diarrhea.

\section{References}

1. WHO. Diarrhoeal disease ; Fact sheet N0 330. 2009 [Cited 2012 May2]. Available from: http://www.who.int/mediacentre/ factsheets/fs330/en/index.html

2. UNICEF/WHO. Why children are still dying and what can be done. New York/ Geneva: 2009 [Cited 2012 May 2]. Available from: whqlibdoc.who.int/ publications/2009/9789241598415_eng. pdf

3. Wilson L. Parasites and how to eliminate them naturally. 2011[Cited 2012 May 2]. Available from: http://drlwilson.com/ Articles/PARASITES.HTM.

4. Haque R, Mondal D, Karim A, Molla IH, Rahim A, Faroque ASG, Ahmad N, Kirkpatrick BD, Houpt E, Snider C, Petri WA et al. Prospective casecontrol study of the association between common enteric protozoal parasites \& diarrhea in Bangladesh.Clin Infect Dis.2009;48(9):1191-7.

5. Uga S, Kimura D, Kimura K, Margono SS. Intestinal parasital infections in Bekasi district,West Java,Indonesia and a comparison of infection rates determined by different techniques for fecal examination. Southeast Asian J Trop Med Public Health. 2002;33(3):462-7.

6. Hazet FA, Roosmini D. Priority determination in infrastructure improving location of water supply and sanitation technology based on public health condition. Bandung: Faculty of Civil and Environment Engineering ITB. [Cited 2012 May 2]. Available from: http://www. ftsl.itb.ac.id/kk/rekayasa_air_dan_limbah_ cair/wp-content/uploads/2010/11/ws2-15304071-frieda-a-hazet.pdf

7. Kecamatan Jatinangor. Potensi Kecamatan Jatinangor Triwulan II Tahun 2009. [Cited 2012 May 2]. Available from: http:// st288653.sitekno.com/article/33924/ potensi.html.

8. Harindi FT, Kamil IM. Application of Small Bore Sewer Di Kecamatan Jatinangor, Kabupaten Sumedang. Bandung: Faculty of Civil and Environment Engineering 
ITB. [Cited 2012 May 2]. Available from: http://www.ftsl.itb.ac.id/kk/rekayasa air_dan_limbah_cair/wp-content/ uploads/2010/11/pe-ww3-finda-tantiaharindi-15305014.pdf

9. Nkrumah B, Nguah SB. Giardia lamblia: a major parasitic cause of childhood diarrhoea in patients attending a district hospital in Ghana. Parasit Vectors. 2011;4:163.

10. WHO. Guidelines for the collection of clinical specimens during field investigation of outbreaks.2000.WHO/ CDS/CSR/EDC/2000.4. [Cited 2012 May 2] Available from: http://apps.who.int/ iris/bitstream/10665/66348/1/WHO_ CDS_CSR_EDC_2000.4.pdf?ua $=1 \&$ ua $=1$

11. Zaglool DAM, Khodari YAW, Gazzaz ZJ, Dhafar KO, Shaker HAS, Farooq MU et al. Prevalence of Intestinal Parasites among Patients of Al-Noor Specialist Hospital, Makkah, Saudi Arabia. Oman Med J. 2011;26(3):182-5.

12. CDC. Amebiasis. Atlanta: DPDx Laboratory Identification of Parasites of Public Health Concern; 2009.[Cited 2012 December 9];Available from: http://www.cdc.gov/ $\mathrm{dpdx} /$ amebiasis /

13. Centers for Disease Control and Prevention. Cryptosporidiosis Surveillance-United States, 2009-2010 and Giardiasis
Surveillance-United States, 2009-2010. MMWR. 2012;61(5):1-19.

14. Assafa D, Kibru E, Nagesh S, Gebreselassie S, Deribe F, Ali J et al.Medical Parasitology. 2004 [Cited 2012 December 9].Available from: http://www.cartercenter.org/ resources/pdfs/health/ephti/library/ lecture_notes/health_science_students/ MedicalParasitology.pdf.

15. Mank TG. The diagnosis and clinical importance of Giardiasis. [Online Journal] 2005 [Cited 2012 December 9]. Available from: http://www.cli-online.com/ fileadmin/pdf/pdf_general/the-diagnosisand-clinical-importance-of-giardiasis.pdf.

16. Cartwright CP. Utility of Multiple-StoolSpecimen Ova and Parasite Examinations in a High Prevalence Setting. J Clin Microbiol. 1999; 37(8):2408-11.

17. Machado ER, De Souza TS, Da Costa JM, Costa-Cruz JMC. Enteroparasites and commnensals among individuals living in rural and urban areas in Abadia dos Dourados, Minas Gerais State. Parasitol Latinoam. 2008;63(1-4):34-9.

18. Kaiser JD. Intestinal Parasites. [Online Journal] 2010 [Cited 2012 December 10]. Available from: http://www.jonkaiser. com/educate/downloads/Intestinal_ Parasites_6-05.pdf. 